\title{
Effectiveness of Practical Integrative Module in Empowering Family Empowering Family of Children with Cerebral Palsy
}

\author{
Linda Harumi ${ }^{1,2)}$, Eti Poncorini Pamungkasari3), Bhisma Murti2) \\ 1)Department of Occupational Therapy, Health Polytechnics, Ministry of Health Surakarta \\ 2)Masters Program in Public Health, Universitas Sebelas Maret \\ 3)Department of Public Health, Faculty of Medicine, Universitas Sebelas Maret
}

\begin{abstract}
Bacground: There is a lack of health care services for children with cerebal palsy (CP) in Indonesia. In addition, family of the children with $\mathrm{CP}$ are lacking in skills of CP services. A simple, practical, easily readable modul of CP services for families of children with CP has been developed. This study aimed to analyze effectiveness of practical integrative module in empowering family empowering family of children with CP.
\end{abstract}

Subject and Method: This was a quasi experimental study, consisting of intervention and control groups without randomization. The study was conducted at Child Growth Clinic Dr. Soedjarwadi hospital, Klaten, and YPAC, Surakarta, Central Java. A sample of 100 families of children with CP was selected for this study by purposive sampling. The sample was divided into two groups: 50 families in the intervention group and 50 families in the control group. The independent variable was practical integrative module of CP handling, i.e. the intervention under study. The dependent variables were knowledge, attitude, and level of family empowerment in CP services. The data were collected by a set of questionnaire and analyzed by linear regression.

Results: After controlling for knowledge before intervention, average knowledge in the intervention group was 0.84 points higher than the control group $(b=0.84 ; 95 \% \mathrm{CI}=0.33$ to $1.86 ; \mathrm{p}$ $=0.002)$. The average attitude in the intervention group was 2.48 points higher than the control group $(b=2.48 ; 95 \% \mathrm{CI}=0.85$ to $4.10 ; \mathrm{p}=0.003)$. The average level of family empowerment in the intervention group was 3.41 points higher than the control group $(b=3.41 ; 95 \% \mathrm{CI}=1.34$ to $5.48 ; \mathrm{p}$ $=0.001$ ).

Conclusion: The integrative module of $\mathrm{CP}$ handling under study is effective in improving knowledge, attitude, and level of family empowerment in families with CP children.

Keywords: knowledge, attitude, empowerment, family, cerebral palsy, children, integrative module, cerebral palsy handling

\section{Correspondence :}

Linda Harumi. Department of Occupational Therapy, Health Polytechnics, Ministry of Health, Surakarta. Email: lindaharumi@ymail.com. Mobile : +68170628006

\section{BACKGROUND}

Cerebral palsy (CP) is a developmental disorder of movement and posture that causes limited activity, caused by permanent lesions in the brain, but not progressive (non progressive), and occurs early in childhood (Miller, 2007). Based on the study of literature conducted by Odding et al., (2009), using the data of the last 40 years in the years 1965 - 2004, the prevalence of $\mathrm{CP}$ increased to above $2.0 \mathrm{per}$
1,000 live births. CP causes delays in almost all aspects of child development, namely, motor development (the most dominant problem in CP children), sensory, cognitive, perceptual, language, communication and behavior (Rosenbaum et al., 2007) which subsequently affects children's inability to do activities (Rosenbaum et al., 2007) in mobility, self-care, playing, academic, interacting in activities in the community and when adult CP is difficult to work. 
Journal of Health Promotion and Behavior (2017), 2(2): 175-184

https://doi.org/10.26911/thejhpb.2016.02.02.07

Families with $\mathrm{CP}$ children have physical, psychological, and socio-economic burdens compared to families with normal children (Davis et al., 2009). According to Gupta and Singhal (2004), the psychological burden of unpreparedness accepts children with $\mathrm{CP}$, pessimism, shame, rejection, guilt, sorrow, withdrawal, helplessness, anger, and depression. Stress is also caused by the negative stigma of large families and society, family conflicts due to $\mathrm{CP}$, and family ignorance about how to care for, and handle CP children. Physical burden caused by the care and handling of $\mathrm{CP}$ children, is quite time consuming. Economic burdens occur in families of middle to lower class families due to large funding needs to access care and education services, and social problems include excluded children, and families have difficulty participating in social activities because they cannot bear to leave their children at home.

The phenomenon that occurs in handling CP children is still based on medical rehabilitation services. Parents have not played much role in handling CP. The development of a child with $\mathrm{CP}$ will be more rapid if the child gets the right treatment. CP handling services are rarely done by families at home due to limited family knowledge about how to handle $\mathrm{CP}$, and the affordability of families to access information on $\mathrm{CP}$ through various media, such as books, internet, videos, consultation with doctors and therapists, as well as the opportunity to attend training and workshops on CP is still limited, and so far not many parents have yet to realize that subjects who must play an important role in handling CP children are families, so children rarely get treatment at home.

The main problem of handling $\mathrm{CP}$ children in Indonesia is that there is no family support with CP children which is indicated by the lack of knowledge, abilities and skills in dealing with CP (Ministry of Women's Empowerment and Child Protection of the Republic of Indonesia, 2011), as well as limited access to health facilities and services. The Indonesian Ministry of Health's Litbangkes Agency (2011) shows that the availability of complete medical rehabilitation services is only in the government class A hospitals (92.5\%) and class B hospitals of $79.3 \%$. the location of hospital types A and B located in the provincial capital or in the city / regency creates distance constraints, and large transportation costs for residents whose homes are far from health services.

The module is a medium for delivering cheap information and can be used by most people compared to audio visual media which not all people have and are able to use audio visual media. Modules cannot really show demonstrations such as videos or training demonstrations, but the module can be read and seen repeatedly. This advantage is useful if there is material that is forgotten, the module user can read it again. Modules are also easy to carry and can be read anywhere. Because of the ease of use the module can be read by all family members in turn. The module has the convenience and benefits as a medium for conveying information, so it is hoped that with the $\mathrm{CP}$ handling module, it can improve family knowledge about CP management, change family attitudes, where families become aware of their role in handling $\mathrm{CP}$ and want to handle $\mathrm{CP}$, and with that module will occur improving family skills in handling CP so that family empowerment can be realized in handling $\mathrm{CP}$, and families can handle $\mathrm{CP}$ without being constrained by costs, distance, and transportation.

The purpose of this study is to analyze the effectiveness of the CP Practical Handling Integrative Module in improving 
family knowledge, attitudes, and empowerment in handling CP.

\section{SUBJECTS AND METHOD \\ 1. Study Design \\ This was a quasi experimental conducted at the Children's Development Clinic at RSJD DR. RM Soedjarwadi, Klaten, and at YPAC, Surakarta, in May-June 2017.}

\section{Population and Samples}

The population of this study was the family of CP children at the Child Growth and Development Clinic RSJD DR. RM. Soedjarwadi, Klaten, and at YPAC, Surakarta of 100 people. The sample selection used was purposive sampling with inclusion criteria for one of the CP family of children with a minimum of high school education (SMA). The sample in this study was given the serial number 0-99. Samples with odd numbers become control groups, and samples with even numbers become treatment groups.

\section{Study Variables}

The independent variables (free) are the provision of $\mathrm{CP}$ handling modules, sample knowledge regarding the treatment of $\mathrm{CP}$ before treatment, family attitudes towards the treatment of $\mathrm{CP}$ before treatment and, the empowerment of $\mathrm{CP}$ family children before treatment.

The dependent variables are the knowledge of the sample regarding the handling of $\mathrm{CP}$ after treatment, family attitudes towards the treatment of $\mathrm{CP}$ after treatment, and the empowerment of the family of CP children after treatment.

\section{Operational definition of variables}

Giving Practical Handling Integrative Module CP in this study is the provision of health promotion media in the form of a complete CP handling module for families who have $\mathrm{CP}$ children with the aim of increasing family empowerment in handling $\mathrm{CP}$.
Knowledge of $\mathrm{CP}$ management is understanding the study subject on the management of CP including knowledge of $\mathrm{CP}$, ways of care and care of $\mathrm{CP}$, appropriate health services for $\mathrm{CP}, \mathrm{CP}$ rights in the community.

Attitudes towards the handling of $\mathrm{CP}$ are awareness, response, and assessment of study subjects on the handling of $\mathrm{CP}$. Attitudes towards handling $\mathrm{CP}$ was measured using an attitude scale regarding the handling of CP.

CP family empowerment is a change in the family of CP children from helpless (not knowing, unwilling, and incapable) handling $\mathrm{CP}$, being empowered (knowing, willing, able) in handling $\mathrm{CP}$ children everyday at home, playing a role in health services or therapies obtained by children, play a role in handling $\mathrm{CP}$ in the community.

\section{Data Collection}

The module Instruments were tested earlier by expert validity tests by 3 experts, 1 module expert, and 2 occupational therapy experts. Knowledge was measured using a knowledge scale questionnaire regarding CP management, attitudes were measured using an attitude scale questionnaire regarding the handling of $\mathrm{CP}$, and empowerment was measured using a CP family empowerment scale questionnaire.

The three questionnaires have been tested for the validity and reliability. Measurement of the instrument validity test in this study was conducted using Pearson Product Moment correlation with the results of the Corrected Item-Total Correlation knowledge scale regarding the handling of $\mathrm{CP} \geq 0.24$, attitude scale regarding the handling of $\mathrm{CP} 250.25$, and the scale of CP family CP 0.3.

The reliability test in this study was analyzed using Alpha Cronbach and the results of Cronbach's Alpha knowledge 
scale on the handling of $\mathrm{CP}=0.82$, attitude scale regarding the handling of $\mathrm{CP}=0.86$, and family empowerment scale $\mathrm{CP}=0.89$.

\section{Data Analysis}

Data collected in this study were analyzed using multiple linear regression statistical tests to analyze:

a. Changes of knowledge after and after getting the module

b. Changes in attitude after and after getting the module

c. Family empowerment before and after getting modules d. Different module effectiveness in the control group and treatment group family population.

\section{RESULTS}

\section{Study Subjects Characteristics}

The results showed that in the intervention group the majority of the study sample were 79 people $(79.0 \%)$, the relationship of the sample with CP children in this study the majority were mothers of 84 people $(84.0 \%)$, and the sample worked as housewives of 65 people (65.0\%).

Table 1. Characteristics of parent's age and child's age

\begin{tabular}{lccccc}
\hline \multicolumn{1}{c}{ Variable } & N & Mean & SD & Min. & Max. \\
\hline Child's age & 100 & 8.59 & 5.17 & 1.50 & 19.00 \\
Parents' age & 100 & 41.73 & 6.85 & 22.00 & 64.00 \\
\hline
\end{tabular}

Table 2. Characteristics of categorical data of study subjects

\begin{tabular}{llcc}
\hline \multicolumn{1}{c}{ Characteristics } & \multicolumn{1}{c}{ Category } & n & \% \\
\hline Education & SSenior high school & 79 & 79.0 \\
Relationship with CP & College & 21 & 21.0 \\
Children & Mother & 84 & 84.0 \\
& Father & 9 & 9.0 \\
& Grandfather & 1 & 1.0 \\
& Grandmother & 5 & 5.0 \\
Occupation & Sibling & 1 & 1.0 \\
& Housewife & 65 & 65.0 \\
& Entrepreneur & 15 & 15.0 \\
& Private & 11 & 11.0 \\
& Labor/employee & 6 & 6.0 \\
& Seller & 2 & 2.0 \\
& Advocate & 1 & 1.0 \\
\hline
\end{tabular}

\section{Effect of practical integrative modules on family knowledge with CP children}

Data analysis used is multivariate analysis using multiple linear regression models, to determine the form of linear relationships between variables and also to determine the contribution of the influence of independent variables on the dependent variable.

Table 5 shows that there is a statistically significant effect of the provision of practical integrative modules on know- ledge, where the average practical integrative module is able to increase knowledge 0.84 points higher than the group not given the module $(b=0.84 ; 95 \% \mathrm{CI}=0.33$ to $1.86 ; \mathrm{p}=0.002$ ). The constant value of 4.88 is the initial knowledge possessed by the sample, while the $\mathrm{R}^{2}=49.9 \%$ indicates that $49.9 \%$ variation in knowledge after the provision of practical integrative modules can be explained by the variables giving practical integrative modules and knowledge before treatment with $\mathrm{p}=0.002$. 
Table 5. The results of multiple linear regression analysis about the effectiveness of providing a practical integrative module on family knowledge regarding the treatment of Cerebral Palsy

\begin{tabular}{lcccc}
\multicolumn{1}{c}{ Variable } & $\mathbf{b}$ & \multicolumn{2}{c}{ CI 95\% } & p \\
\cline { 3 - 4 } & & Lower Limit & Upper Limit & \\
\hline Constant & 4.88 & 2.41 & 7.35 & $<0.001$ \\
Intervensi modul & 0.84 & 0.33 & 1.36 & 0.002 \\
Pengetahuan Pretest & 0.69 & 0.55 & 0.84 & $<0.001$ \\
n observasi $=100$ & & & & \\
Adjusted $\mathrm{R}^{2}=49.9 \%$ & & & & \\
p $\leq$ 0.001 & & & \\
\hline
\end{tabular}

4. The influence of practical integrative modules on the attitudes of families with CP children

This multiple linear regression model was used to determine the effect of giving practical integrative modules on family attitudes in handling CP.

Table 6 shows that there was a statistically significant effect on the implementation of practical integrative modules on attitudes, where the average practical integrative module is able to increase attitudes

Table 6. The results of multiple linear regression analysis about the effectiveness of giving practical integrative modules to family attitudes in handling CP

\begin{tabular}{lcccc}
\hline \multirow{2}{*}{ Variable } & \multirow{2}{*}{$\mathbf{b}$} & \multicolumn{2}{c}{ CI 95\% } & \multirow{2}{*}{ p } \\
\cline { 3 - 4 } & & Lower Limit & Upper Limit & $<0.001$ \\
(Constant) & 20.47 & 15.09 & 25.86 & $<.003$ \\
Module intervention & 2.48 & 0.85 & 4.10 & 0.003 \\
Attitude Pretest & 0.51 & 0.38 & 0.63 & $<0.001$
\end{tabular}

n observation $=100$

Adjusted $\mathrm{R}^{2}=41.9 \%$

$\mathrm{p} \leq 0.001$

5. The effect of practical integrative modules on family empowerment with CP children

This multiple linear regression model was used to determine the effect of practical integrative modules on empowerment.

Table 7 showed that there was an effect of providing a practical integrative module that was statistically significant on the level of family empowerment in handling $\mathrm{CP}$, giving an average practical integrative module was able to increase the empowerment by 3.41 points higher than by 2.48 points higher than the samples that are not given modules $(b=2.48 ; 95 \% \mathrm{CI}=$ 0.85 to $4.10 ; p=0.003$ ). A constant value of 20.47 is the initial attitude that a sample has with a CP child. While the R2 value of $41.9 \%$ shows that as much as $41.9 \%$ of variations in attitude after the provision of practical integrative modules can be explained by the variables giving practical integrative modules and attitudes before treatment with $\mathrm{p}=0.003$. 
Journal of Health Promotion and Behavior (2017), 2(2): 175-184

https://doi.org/10.26911/thejhpb.2016.02.02.07

empowerment after doing the treatment in the form of giving a practical integrative module, the samples who got practical

integrative modules would experience better empowerment than samples that did not receive practical integrative modules.

Table 7. The results of multiple linear regression analysis about the effectiveness of practical integrative modules on the level of empowerment

\begin{tabular}{lcccc}
\hline \multirow{2}{*}{ Variables } & \multirow{2}{*}{ b } & \multicolumn{2}{c}{ CI 95\% } & \multirow{2}{*}{ p } \\
\cline { 3 - 4 } & & Lower Limit & Upper Limit & \\
\hline (Constant) & 36.16 & 29.35 & 42.97 & 0.001 \\
Module Intervention & 3.41 & 1.34 & 5.48 & 0.001 \\
Empowerment Pretest & 0.22 & 0.08 & 0.36 & 0.002 \\
n observation = 100 & & & & \\
Adjusted $\mathrm{R}^{2}=13.0 \%$ & & & \\
$\mathrm{p} \leq$ 0.001 & & & \\
\hline
\end{tabular}

\section{DISCUSSIONS}

\section{The Effect of Practical Integrative Modules on Family Knowledge about CP Handling}

The result of this study showed that there was an effect of practical integrative modules on knowledge which was statistically significant, where the provision of practical integrative modules could increase the knowledge by 0.84 points higher than the group that did not receive a module $(b=0.84 ; 95 \% \mathrm{CI}=0.33$ to $1.86 ; \mathrm{p}=0.002$ ). This result was in line with a study done by Hastuti and Mahaningsih (2008) which stated that educational media in the form of modules allowed the delivery of material to be in-depth because it contained material in a more complete and detailed manner, so that readers would be more easily to understand the material, in addition, the module allowed the readers to learn the material independently and repeatedly.

The score of $\mathrm{R}^{2}=49.9 \%$, it indicated that $49.9 \%$ of variations in knowledge after receiving practical integrative modules were supported by the provision of practical integrative modules and pre-treatment knowledge. The sample knowledge regarding the handling of $\mathrm{CP}$ before obtaining a Practical Integrative Module was possible to be obtained by the family because most children with $\mathrm{CP}$ in this study have received therapy for more than 1 year so that the family has been more or less exposed to knowledge about how to handle $\mathrm{CP}$, the basis of this knowledge was increased with the provision of CP handling information in the form of an integrative module of CP handling for families. A study done by Arifah (2010) showed that there was a significant difference in knowledge between the group that received the module and the group that did not receive the module. The module was more effective in increasing sample knowledge that was known from the results of the post test.

Increased knowledge according to Budiman and Riyanto (2013) was also affected by factors of education, information from mass media, social, cultural, economic, environmental, experience, and age. The families of children with $\mathrm{CP}$ were high school and vocational education graduates, so it can be concluded that the family was able to understand the contents of the module and was able to apply the module in handling the children with $\mathrm{CP}$. The information factor in this study was obtained from a practical integrative module, in addition, it was also added from various other sources (doctors, therapists, training, and social media) obtained before getting practical integrative modules. Social, economic, and cultural factors in 
this study showed that most of the samples were mothers who were housewives (65\%), where mothers could arrange their time flexibly to read modules and apply it to their children. From the cultural factors, it showed that mothers played the main role of childcare, so that the mothers would try to get the information in nurturing their children who have CP. Increased knowledge was also supported by the age of the parents in this study. Minimum age of family was 22 years old and the maximum age was 64 years old, the average age of a family was a productive age, which was a mature age in thinking and working.

\section{The Effect of Practical Integrative Modules on Attitude}

The result of this study showed that there was an effect of practical integrative modules on attitude which was statistically significant, where the provision of practical integrative modules could increase the knowledge by 2.48 points higher than the group that did not receive a module $(\mathrm{b}=$ 2.48; $95 \% \mathrm{CI}=0.85$ to $4.10 ; \mathrm{p}=0.003) . \mathrm{A}$ study done by Muhaimin et al., (2012) showed that there was a difference in average knowledge and attitudes before and after health education interventions. However, the average was still higher in the treatment group, it mean that health education in the treatment group affected the differences in knowledge and attitudes of treatment groups before and after health education interventions.

A study conducted by Kholik (2006) also showed that book media was more effective in improving family attitudes in preventing DHF. Modules or books could give new information. New information could be a new cognitive foundation for the formation of an attitude, if the information was strong enough, suggestive messages would provide an affective basis in assess- ing things so that a certain attitude was formed (Florian and Findler, 2001)

A constant score of 20.47 was the initial attitude possessed by the sample with $\mathrm{CP}$ children. While the value of $\mathrm{R} 2=$ $41.9 \%$, it indicated that $41.9 \%$ of variations in attitudes after the provision of practical integrative modules could be explained by the variables of practical integrative modules and attitudes before treatment. In addition to providing practical integrative modules, this attitude improvement was also influenced by the initial attitude of the family regarding the handling of CP. A study entitled "Vanderbilt Caregiver Empowerment Project" by Bickman et al., (1998) illustrated that the caregiver's knowledge and self-efficacy at the beginning of the training also affected the improvement of self-efficacy and knowledge which ultimately lead to greater caregiver involvement in mental health services. The attitude owned by the parents before getting a module has an effect in this study.

Azwar (2007) stated that factors that affect the attitude formation were personal experience, culture, other people who were considered important, mass media, educational institutions, religious institutions, and emotional factors in individuals. Personal experience factors as well as personal emotional factors in individuals played a role in changing the attitudes in this study. The presence of children with CP in the family clearly gave an emotional impact on the family. From the interviews with several samples, families wanted their children to grow and develop like other normal children, and also hoped that their children can be independent, go to school, and have a job later. These hopes further shaped the family's attitude toward the handling of CP and encouraged an attitude toward a positive direction, which was to strive for maximum child care that they could get. 
Journal of Health Promotion and Behavior (2017), 2(2): 175-184

https://doi.org/10.26911/thejhpb.2016.02.02.07

The results of the questionnaire recapitulation of the pretest attitude obtained an average score of 42 from the total value of 52 attitude scale, which mean that the family of children with $\mathrm{CP}$ in this study had a positive attitude in handling $\mathrm{CP}$, and it was increased after obtaining practical integrative modules of $\mathrm{CP}$ handling with an average score of attitude scale by 44 .

\section{The Effect of Practical Integrative Modules on Empowerment}

The result of this study showed that there was an effect of practical integrative modules on empowerment which was statistically significant, where the provision of practical integrative modules could increase the empowerment by 3.41 points higher than the group that did not receive a module $(\mathrm{b}=3.41 ; 95 \% \mathrm{CI}=1.34$ to $5.48 ; \mathrm{p}=$ $0.001)$. This was in accordance with a study done by Anggraini (2015) which stated that there was an effect of module learning on maternal skills in stimulating toddlers' growth and development.

Anwar (2010) defined the module as a form of instructional materials that were arranged systematically and attractively so that they were easy to learn independently to achieve the expected competencies. Expected competencies in the study were family empowerment in the form of increasing knowledge, attitudes, and family empowerment in handling $\mathrm{CP}$, and the results of this study showed positive results for the achievement of these competencies.

A constant score of 36.16 was the initial empowerment of the sample with CP children. The score of $\mathrm{R}^{2}=13.0 \%$, it indicated that $13.0 \%$ of variations in empowerment after the provision of practical integrative modules could be explained by the variables of practical integrative modules and empowerment before treatment. The results of this study showed that the enhancement of empowerment was affected by empowerment before the treatment. This was indicated by the average score of a fairly good empowerment scale before the treatment of 44.42, from the total score of empowerment scale of 60 increased to 49.44 after getting the module.

Empowerment was the process of providing information and assistance to individuals, families or groups (clients) to overcome health problems on an ongoing basis, as well as the process of changing, so that clients could be aware (aspects of knowledge), from knowing to be willing (attitude aspect), and from willing to be able to conduct the expected behavior (Minister of Health RI, 2013).

The increase in empowerment in this study did not occur instantly. Before being treated in the form of modules, each sample has the knowledge, attitude, and empowerment in dealing with $\mathrm{CP}$ children. Giving the modules, the knowledge, attitude, and empowerment that they possessed were increased with the process: increased knowledge of the modules provided which was followed by an increase in attitudes, and subsequently there was an increase in family empowerment in $\mathrm{CP}$ handling. This process was also in accordance with the information-motivation-behavioral skills that if someone got health information properly, he or she would be motivated to conduct, have the skills, and confident to take an action, and then the individual would begin and maintain health behaviors that would produce positive results (Fisher et al., 2003). Based on the theory of Green (1980) factors that influenced health behavior were predisposing factors which were affected by knowledge, attitudes, beliefs, and values. The enabling factors were influenced by the availability of facilities, and reinforcing factors were affected by family attitudes, community attitudes, and 
the behavior of health personnels or model groups of other community behaviors.

Based on the results of this study, it can be concluded that predisposing factors were affected by the knowledge presented in the practical integrative module and the interpretation of readers based on prior knowledge and experience of the sample. Enabling factors in the form of availability of knowledge on how to handle CP in the form of modules, where the contents of the module were easy to implement, because they contained training procedures, presented by pictures, and the tools used were easily to get in the environment around the family.

Reinforcing factors were given in the form of direct explanation of module use, as well as written explanation in the module, and positive family attitudes before treatment, and it increased by the treatment to treat the children with $\mathrm{CP}$. Because the three factors have been fulfilled, therefore, there was a change in health behavior in the form of increasing family empowerment in CP handling.

\begin{tabular}{l}
\hline REFERENCES \\
\hline Anggraini VE (2015). Pengaruh Pembela- \\
jaran Modul Stimulasi terhadap Ting- \\
kat Keterampilan Ibu dalam Mensti- \\
mulasi Tumbuh Kembang balita (3-5 \\
Tahun) di Desa Sinduadi, Mlati, \\
Sleman, Yogyakarta.
\end{tabular}

Anwar I (2010). Pengembangan Bahan Ajar. Bandung: Direktori Upi.

Azwar S (2007). Penyusunan Skala Psikologi. Yogyakarta: Pustaka Pelajar.

Badan Litbangkes Kementerian Kesehatan RI (2011). Laporan Akhir Riset Fasilitas Kesehatan 2011 Rumah Sakit. Kementerian Kesehatan RI.

Bickman L, Heflinger CA, Northrup D, Sonnichsen S, Schilling, S (1998). Longterm outcomes to family caregiver empowerment. Journal of Child and Family Studies, 7, 269-282.

Budiman RA (2013). Kapital Selekta Kuesioner: Pengetahuan dan Sikap dalam Penelitian Kesehatan. Jakarta: Salemba Medika.

Davis E, Shelly A, Waters E, Boyd R, Cook, $\mathrm{K}$, Davern M (2009). The impact of caring for a child with cerebral palsy : Quality of life for mothers and fathers. Child: Care, Health and Development. 36(1): 63-73. doi: 10.1111/j.1365-2214.2009. 00989.x

Fisher WA, Fisher JD, Harman J (2003). The Information-Motivation-Behavioral Skills Model: A General Social Psychological Approach to Understanding and Promoting Health Behavior. In: Social Psychological Foundations of Health and Illness. Victoria, Australia: Australia Blackwell Publishing, Ltd; 82-106.

Florian V, Findler L (2001). Mental Health and Marital Adaptation Among Mothers of Children With Cerebral Palsy. Am J Orthopsychiatry, 71:358-367.

Green LW (1980). Health Education Planning: A Diagnostic Approach. (1st Edition). California: Mayfield Publishing Company.

Gupta A, Singhal N (2004). Perceptions in parents of children with disabilities. Asia Pacific Disability Rehabilitation Journal, 15(1): 22-35.

Hastuti P, Mahaningsih L (2008). Efektifitas Pendidikan Kesehatan dengan Menggunakan Modul dan Presentasi yang Disertai Selebaran Terhadap Pengetahuan Tentang HIV/AIDS pada siswa SMUN 3 dan SMUN 1 Panjangan Kabupaten Bantul Tahun 2008. Jurnal Kebidanan. 4(1): 109.

Kementerian Kesehatan Republik Indonesia (2013). Peraturan Menteri Kesehatan Republik Indonesia Nomor 65 
Tahun 2013 Tentang Pedoman Pelaksanaan Dan Pembinaan Pemberdayaan Masyarakat Bidang Kesehatan.

Kementerian Negara Pemberdayaan Perempuan Dan Perlindungan Anak Republik Indonesia (2011). Peraturan Menteri Negara Pemberdayan Perempuan dan Perlindungan Anak Republik Indonesia Nomor 10 Tahun 2011 Tentang Kebijakan Penanganan Anak Berkebutuhan Khusus.

Kholik S (2006). Media Kalender Sebagai Media Penyuluh dalam meningkatkan Pengetahun, Sikap dan Periaku Dalam Pencegahan DBD di Kecamat- an Landasan Ulin Kota Banjarbaru. Tesis. Yogyakarta: Pasca Sarjana, PSIKM, UGM

Miller F (2007). Physical Therapy of Cerebral Palsy. New York: Springer Science and Bussiness Inc.

Odding E, Roebroeck ME, Stam HJ (2009). The Epidemiology of Cerebral Palsy: Incidence, Impairments and Risk Factors. Journal Disability and Rehabilitation, 28: 183-191.

Rosenbaum P, Paneth N, Leviton A (2007). A Report: The Definition and Classificastion of Cerebral Palsy. Dev Med Child Neurol. 109:8-14 